\title{
Revista Brasileira de Fruticultura \\ Phenology of the production of flowers and fruits of wild and hybrid species of the genus Passiflora
}

\author{
Danilo Akio de Sousa Esashika ${ }^{1}$, Fábio Gelape Faleiro ${ }^{2}$, Nilton Tadeu Vilela Junqueira ${ }^{3}$
}

Abstract - Wild species of passion fruit have characteristics that could be used in the passiflora culture, among them the production of fruits in the off-season of the sour passion fruit. The objective of this work was to evaluate the phenology of flowers and fruits production in wild species cultivated in the Brazilian Savanna Central Region. For each access, a 1-meter-long strip $\left(2 \mathrm{~m}^{2}\right)$ was evaluated for the presence of flowers and fruits from January 2015 to December 2016. The hybrid and wild species of passiflora that produce floral buds, flowers and fruits during the off-season of passion fruit sour include: BRS Céu do Cerrado ( $P$. incarnata $x$ P. edulis), $P$. alata Dryand, P. bahiensis Klotzsch, P. coccinea Aubl., P. maliformis L., P. quadriglandulosa Rodschied, P. auriculata Kunth, P. decaisneana G. Nicholson, P. sidifolia M. Roem., P. suberosa L., $P$. tholozanii Sacco, $P$. quadrangularis $x P$. alata. It was also verified the presence of species and hybrids with high ornamental potential due to the beauty of their flowers and their production during the whole year, such as: $P$. suberosa L., P. tholozanii Sacco, P. coccinea $\times$ P. setacea, $P$. coccinea $\mathrm{x} P$. quadrifaria. These species and hybrids have high potential for passiflora breeding programs as a source of genes of interest.

Index terms: passion fruit, pre-breeding, ornamental, off-season production.

\section{Fenologia da floração e frutificação de espécies silvestres e híbridos de Passiflora}

Corresponding author:

E-mail: fabio.faleiro@embrapa.br

Received: April 12, 2017.

Accepted: November 08, 2017.

Copyright: All the contents of this journal, except where otherwise noted, is licensed under a Creative Commons Attribution License.
Resumo - Espécies silvestres de maracujazeiro possuem características que poderiam ser utilizadas na passicultura, dentre elas a produção de frutos na entressafra do maracujazeiro-azedo. Neste trabalho, objetivou-se avaliar a fenologia da produção de botões florais, flores e frutos em espécies silvestres cultivadas no Cerrado do Planalto Central. Para cada acesso, uma faixa de 1 metro de espaldeira $\left(2 \mathrm{~m}^{2}\right)$ foi avaliada quanto à presença de botões florais, flores e frutos, de janeiro de 2015 a dezembro de 2016. Verificou-se a presença de maracujazeiros silvestres e híbridos que produzem estruturas reprodutivas no período de entressafra do maracujazeiro-azedo, sendo eles: BRS Céu do Cerrado (P. incarnata $x$ P. edulis), P. alata Dryand, P. bahiensis Klotzsch, P. coccinea Aubl., P. maliformis L., P. quadriglandulosa Rodschied, , P. auriculata Kunth, P. decaisneana G. Nicholson, P. sidifolia M. Roem., P. suberosa L., P. tholozanii Sacco, P. quadrangularis x P. alata. Verificou-se também a presença de espécies e híbridos com elevado potencial ornamental devido à beleza de suas flores e à produção das mesmas durante o ano inteiro, sendo elas: $P$. suberosa L., $P$. tholozanii Sacco, P. coccinea x P. setacea e P. coccinea x $P$. quadrifaria. Estas espécies e híbridos possuem elevado potencial para os programas de melhoramento de passifloráceas como fonte de genes de interesse.

Termos de indexação: maracujá, pré-melhoramento, ornamental, entressafra. 


\section{Introduction}

The most commonly species of passion fruit cultivated in the country (Passiflora edulis Sims, sour passion fruit) has phenological features that result in seasonal harvest in the South, Southeast and Midwest part of Brazil. This can be considered as one of the most important aspects to be improved by the genetic breeding.

Sour passion fruit is a long-day plant able to present flower buds after being exposed to light periods longer than 11 hours and 20 minutes (WATSON and BOWERS, 1965; MENZEL and SIMPSON, 1998; CAVICHIOLI, 2009). Under 15 degrees South latitude this condition is not met from May to August and results in an off-season period in the second semester of the year, when the production decreases and prices tend to increase.

Other environmental factors considered potential causes for seasonality include: temperatures lower than $15^{\circ} \mathrm{C}$ that will result in flower buds drop (PIZA JÚNIOR, 1991; JUNQUEIRA et al., 2001); lack of water also inducing to a drop of flower buds (TEIXEIRA, 1994; MELETTI, 1995); and low relative humidity/lack of pollinating agents in the field making the pollination and fertilization process of the passion fruit flowers difficult, a crucial process to fruit filling and adequate production.

Besides being able to select $P$. edulis individuals insensitive to the photoperiod, there is also the alternative to select plants with this feature in all genetic base of the genus Passiflora, having the advantage of adding the feature "resistance to biotic and abiotic factors" presented by several wild species of this genus (JUNQUEIRA et al., 2005; JUNQUEIRA et al., 2006). Therefore, the opportunity to identify species of passiflora with sour passion fruit off-season production in order to add this characteristic to commercial passion fruit trees breeding programs to start as well as continue wild species breeding programs is real. The purpose of the present study is to evaluate the phenology of the production of flowers and fruits of wild and hybrid species of the genus Passiflora in the Brazilian Savanna Central Region.

\section{Material And Methods}

The experiment was performed from January 2015 to December 2016 at Embrapa Cerrados Experimental Station located in Planaltina-DF, with the following geographic coordinates: 15\%36'11" South latitude, 47 $43^{\prime}$ '12" West longitude and 1007 meters altitude. The climate in this region is classified as AW Tropical according to Köppen. Figs. 1 and 2 show the temperature, rainfall and relative humidity.

The soil at the experimental site is red latosol with a clay texture and high levels of phosphorus and potassium and proper $\mathrm{Ca} / \mathrm{Mg}$ ratio as shown in Table 1 . The conventional and topdressing fertilization were made as recommended for sour passion fruit cultivation in the Midwest of Brazil, so that the plants would not experience nutritional deficiencies. A drip irrigation system with a 4-day irrigation frequency was used where each plant received approximately 30 liters of water.

The region meets the requirements for a light exposure of 11 hours and 20 minutes so that the sour passion fruit (Passiflora edulis) will be able to form floral buds (WATSON and BOWERS, 1965; MENZEL and SIMPSON, 1998).

Thirty-four accessions of Passiflora from Active Germplasm Bank 'Flor da Paixão' (Figure 3) were evaluated. The plants of each access kept in vivo were cloned through cutting to produce seedlings. Eight seedlings of each access were grown in the field in vertical espaliers in two wires, which were about two meters high. All plants were daily cultivated according to technical recommendations for the sour passion fruit cultivation.

For each access, a 1-meter-long strip $\left(2 \mathrm{~m}^{2}\right)$ was evaluated for the presence and number of floral buds, flowers and fruits. A modified GANNT chart was used to analyze through descriptive statistics the data for the presence or absence of flowers and fruits.

Table 1 - Soil analysis results of the experimental area, 2014.

\begin{tabular}{cccccccc}
\hline $\mathrm{pH}\left(\mathrm{H}_{2} \mathrm{O}\right)$ & $\begin{array}{c}\mathrm{Al} \\
(\mathrm{ppm})\end{array}$ & $\begin{array}{c}\mathrm{P}_{\text {Mehlich }} \\
(\mathrm{ppm})\end{array}$ & $\begin{array}{c}\mathrm{K} \\
(\mathrm{ppm})\end{array}$ & $\begin{array}{c}\mathrm{Ca} \\
\left(\mathrm{meq} / \mathrm{cm}^{3}\right)\end{array}$ & $\begin{array}{c}\mathrm{Mg} \\
\left(\mathrm{meq} / \mathrm{cm}^{3}\right)\end{array}$ & $\begin{array}{c}\mathrm{H}+\mathrm{Al} \\
\left(\mathrm{meq} / \mathrm{cm}^{3}\right)\end{array}$ & M.O. (\%) \\
\hline 6.4 & 0.0 & 47.7 & 170.0 & 3.8 & 1.2 & 2.8 & 2.4 \\
\hline
\end{tabular}

\section{Results and Discussion}

Passion fruit species and hybrids that produce floral buds, flowers and fruits in the off-season period of the sour passion fruit in the Federal District (August to November) are: BRS Céu do Cerrado (P. incarnata $x P$. edulis), $P$. alata Dryand, $P$. bahiensis Klotzsch, $P$. coccinea Aubl., P. maliformis L., P. quadriglandulosa Rodschied,
P. auriculata Kunth, P. decaisneana G. Nicholson, $P$. sidifolia M. Roem., P. suberosa L., P. tholozanii Sacco and $P$. quadrangularis $\times$ P. alata (Figure 3).

BRS Céu do Cerrado (P. incarnata $x$ P. edulis) cultivar produced flowers and floral buds in July (Figure 3 ), the most difficult time for sour passion fruit in the region of the Federal District, because besides having a reduced photoperiod and it is a period of low temperatures 
and relative humidity (Figures 1 and 2) that decreases the pollination viability and provoke the abortion of floral buds, flowers and fruits. The production of flowers and floral buds in this period of time and fruits in July, August and September might be attributed to a feature characteristic to $P$. incarnata $\mathrm{L}$. which is the resistance to cold (up to $-16^{\circ} \mathrm{C}$ ) (VANDERPLANK, 1991; WINKS et al. 1988). Hybridization between the two species made by other authors show interesting features such as resistance to cold (WINKS et al., 1988), resistance to Passionfruit woodiness virus (PWV) (WINKS et al., 1988) and presence of a sweetened pulp in fruits with a good commercial quality (SENTER et al., 1993).

Accessions of $P$. alata Dryand (CPAC - MJ-02-17, CPAC - MJ-02-09, CPAC - MJ-02-19) produce floral buds and flowers in periods of time when the photoperiod is shorter, the temperature is lower (June to August) (Figure 1) and fruit production in the following two months (September to October), the off-season months for the sour passion fruit tree (Figure 3). This species is compatible to several passiflora species such as: $P$. setacea, P. mucronata, P. galbana, P. edulis and P. quadrangulares (SOUZA et al., 2008). This feature makes it a potential source of genes for the cultivation in the off-season period as verified with the hybrid $P$. quadrangularis $x P$. alata (CPAC-MJ -H-44) that probably inherited this "off-season production" feature from $P$. alata since $P$. quadrangularis L. (CPAC MJ-07-03) did not produce fruits from August to November (Figure 3).

The accession named CPAC MJ-58-0, P. maliformis L., showed an intense off-season production, being insensitive to the photoperiod and lower temperatures. Since 2000, genetic breeding programs for this species have been performed at Embrapa Cerrados using a recurrent selection from different accessions collected at the savanna region and the Amazon in the states of Roraima and Rondônia (TELES et al., 2012; SILVA, 2017). The purpose of the species breeding has been to increase the productivity, yield larger and sweeter fruits with a thinner peel and more pulp, besides a better adjustment to the savanna and resistance to diseases such as anthracnose, viruses and fusariosis (TELES et al., 2012; SILVA, 2017).

As for $P$. coccinea, it is compatible with commercial passion fruit plants such as $P$. edulis Sims and P. alata Dryand, yielding viable seeds in these crossings. The results from this present study evidenced that CPAC MJ-08-05 produced floral buds, flowers and fruits in the sour passion fruit off-season period. Faleiro et al. (2011) reported that in environmental conditions of the Brazilian Midwest this species behaves as a short-day plant, blooming in the period where the days are shorter (May, June and July), with a harvesting period from August to October. Accession CPAC MJ-08-05 produced flowers in several months of the year, while CPAC MJ-08-01 showed a fruit production concentrated in May, June, October and November (Figure 3). Besides that, $P$. coccinea has other features that makes it a great source of genes like resistance to bacteriosis and anthracnose (FALEIRO et al., 2011).

Little information was found for P. quadriglandulosa Rodschied. Among its uses, it has been used as a medicinal plant according to Martin and Nakasone (1970). Its production was observed in September and October, although it produced flowers and floral buds in the first three months in 2015 but with no fruits, evidencing that the condition for fruit yield was not met at this period of time.

$P$. auriculata Kunth produced flowers and fruits for a month, several times of the year, including during the sour passion fruit off-season in 2015 (Figure 3). There were not a lot of information about its compatibility with commercial passion fruit trees and resistance to diseases. The quality of fruits that although small are appreciated for being sweet in their countries of origin, from Nicaragua to the Peruvian, Bolivian and Brazilian Amazon (VÁSQUEZ and COIMBRA, 1996) is highlighted.

P. tholozanii Sacco had flowers and floral buds in approximately all months from January 2015 to December 2016 (Figure 3). In their region of origin, in the states of Amazonas, Pará, Amapá and Mato Grosso, it blooms from August to November and produces fruits from November to February (CERVI and DUNAISKI JUNIOR, 2004).

CPAC MJ-35-01 and CPAC MJ-35-02, both belonging to the $P$. suberosa species, presented a high production of floral buds, flowers and fruits several months of the year. The second accession showed a continuous production of the floral buds, flowers and fruits during the studying period. However, the literature does not show information on its compatibility with commercial species. This species might be an important source of genetic resource for passiflora breeding programs, since besides showing accentuated seasonality it is also auto-compatible. This is an important feature because it increases the fruit production index, reducing the labor with artificial pollination and impact of African bees (ACIOLI, 2003; FALEIRO et al., 2011).

There is no information available on the biology regarding $P$. decaisneana $\mathrm{G}$. Nicholson and $P$. sidifolia M. Roem, evidencing the need of further studies on these species since both of them have productions from June to December, off-season period for P. edulis Sims.

It was also observed that species and hybrids like $P$. coccinea Aubl., P. suberosa L., P. coccinea $\mathrm{x}$ P. setacea, $P$. coccinea $\times$ P. quadrifaria e $P$. tholozanii Sacco were able to produce flowers every single month of the year (Figure 3). 
P. coccinea $\mathrm{x}$ P. setacea (CPAC MJ-H-01) and $P$. coccinea $\mathrm{x} P$. quadrifaria (CPAC MJ-H-50) produced flowers all year round. P. coccinea $\mathrm{x} P$. setacea (CPAC MJ-H-01) did not produce fruits, while $P$. coccinea $\times$. quadrifaria (CPAC MJ-H-50) yielded fruits even with a high production of flowers, maybe because of the autoincompatibility and the fact they are inter-specific hybrids.

64

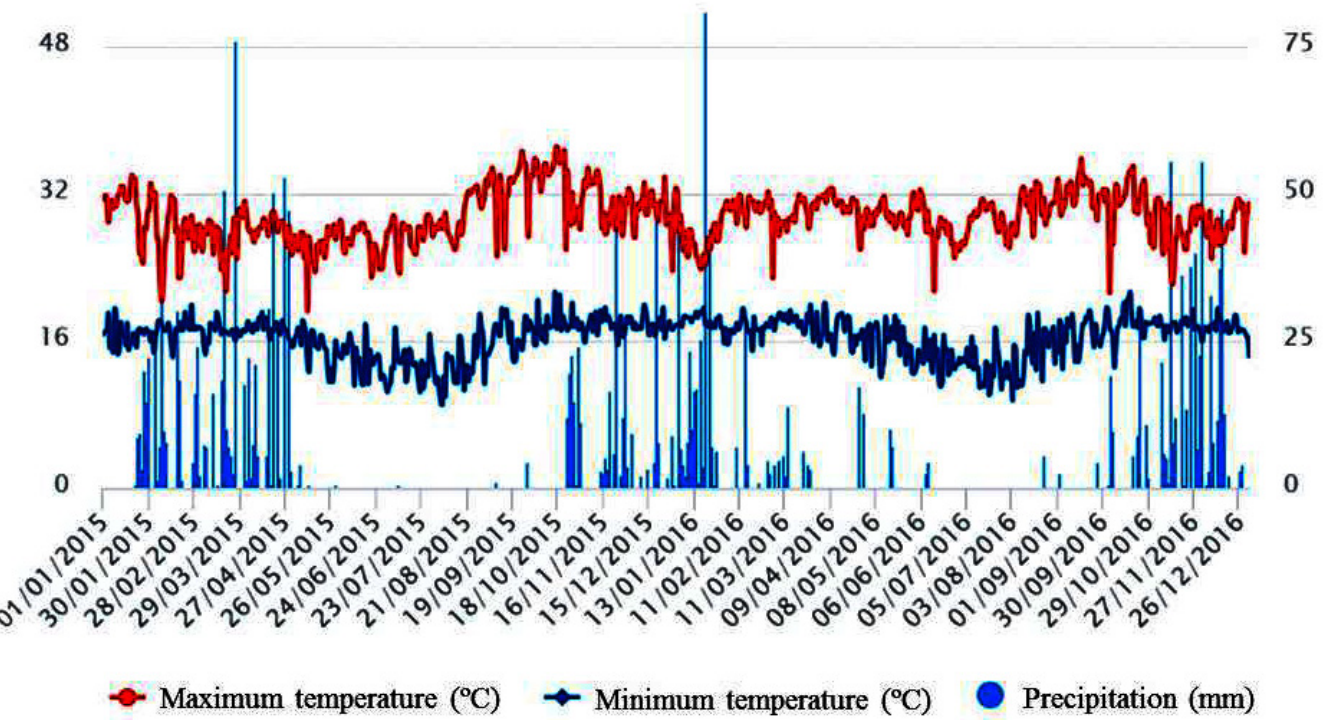

Figure 1- Precipitation, maximum and minimum temperatures from 2015 to 2016. Planaltina-DF, 2017.

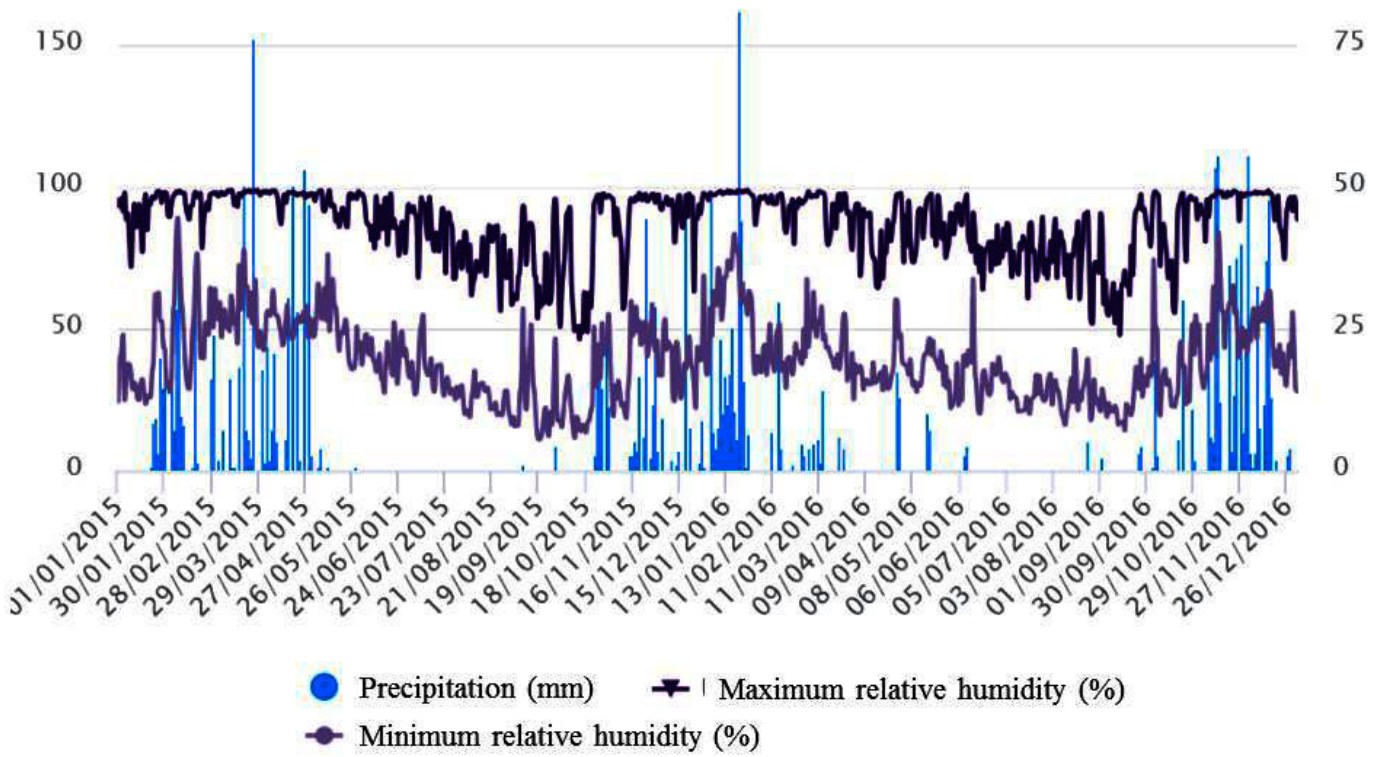

Figure 2- Precipitation, max/min relative humidity from 2015 to 2016. Planaltina-DF. 
Figure 3- Floral buds, flowers (green) and fruits (red) production by the genus Passiflora accessions under the conditions presented by the savanna in the Brazilian Central Plateau, Embrapa Cerrados 2015 - 2016.

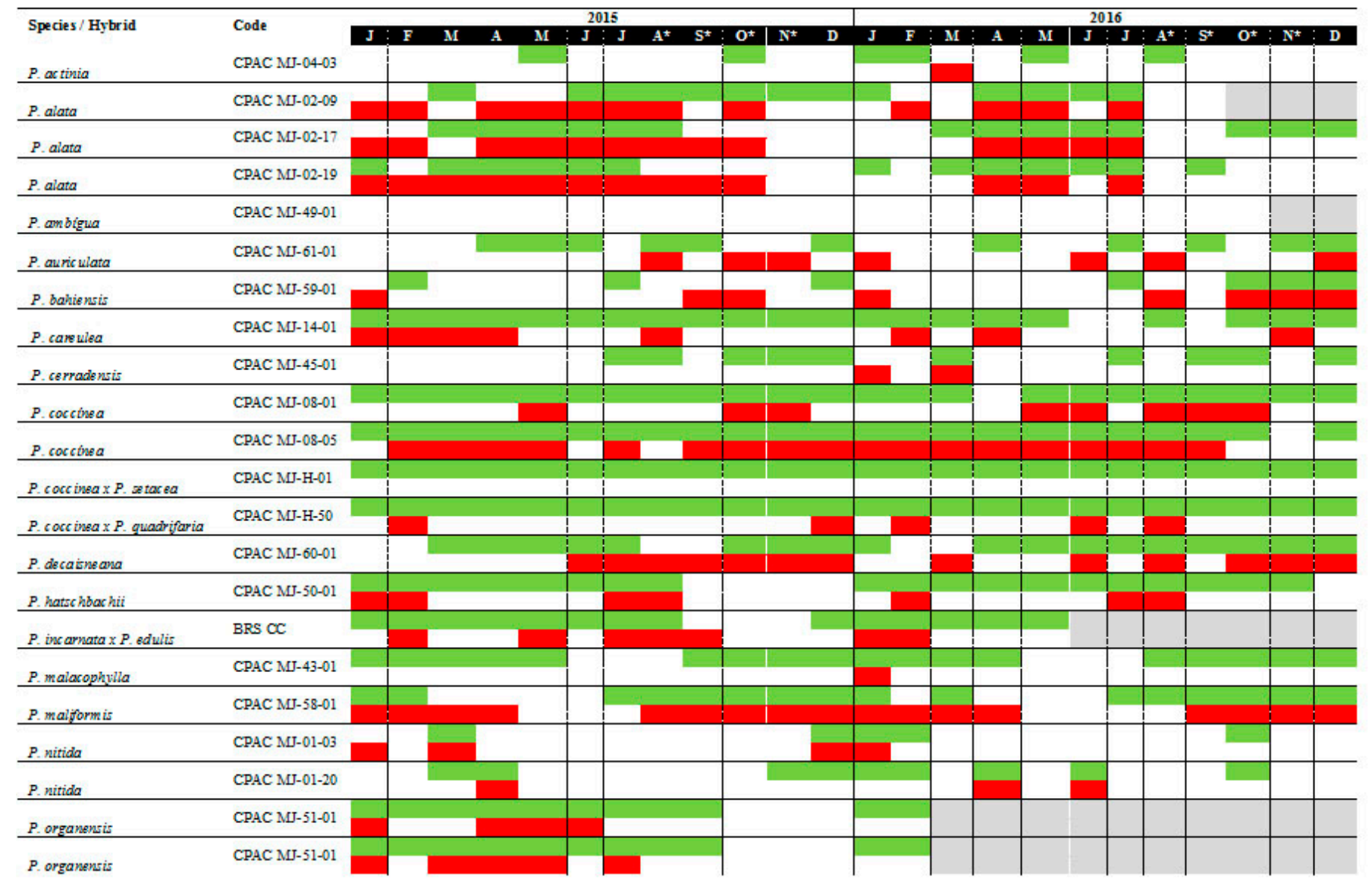

* The marked months represent the sour passion fruit off-season in the Federal District. Note: The gray cells indicate the death of evaluated plants.

\section{Conclusions}

The following species and hybrids: BRS Céu do Cerrado (P. incarnata x P. edulis), P. alata Dryand, $P$. bahiensis Klotzsch, $P$. coccinea Aubl., P. maliformis L., $P$. quadriglandulosa Rodschied, P. auriculata Kunth, P. decaisneana G. Nicholson, P. sidifolia M. Roem., P. suberosa L., P. tholozanii Sacco, P. quadrangularis $\mathrm{x}$ $P$. alata show a high potential for passiflora breeding programs as a source of genes that allow the production in the off-season period of P. edulis Sims.

On the other hand, $P$. coccinea Aubl., P. suberosa L., $P$. tholozanii Sacco, P. coccinea x P. setacea, $P$. coccinea $\mathrm{x} P$. quadrifaria species and hybrids show a high ornamental potential due to the beauty of their flowers constantly produced throughout the year.

\section{References}

ACIOLI, M. F. Ecologia da polinização de Passiflora suberosa Linnaeus (Passifloraceae). 2003. 82 f. Tese (Doutorado em Ecologia) - Instituto de Biociências, Universidade Federal do Rio Grande do Sul, Porto Alegre, 2003.

CAVICHIOLI, J. C. Florescimento e frutificação do maracujazeiro-amarelo submetido à iluminação artificial, irrigação e sombreamento. Revista Brasileira de Fruticultura, Jaboticabal, v.28, n.1, p.92-96, 2009.

CERVI, A.C.; DUNAISKI JR., A. Passifloraceae do Brasil: estudo do gênero Passiflora L. subgênero Distephana (Juss.) Killip. Revista Estudos de Biologia, Curitiba, v. 26, n. 55, p.45-67, 2004. 
FALEIRO, F. G.; JUNQUEIRA, N. T. V.; BRAGA, M. F.; OLIVEIRA, E. J.; PEIXOTO, J. R.; COSTA, A. M. Germoplasma e melhoramento genético do maracujazeiro: histórico e perspectivas. Planaltina: Embrapa Cerrados, 2011. p. 36. (Documentos, 307).

JUNQUEIRA, N.T.V.; BRAGA, M.F.; FALEIRO, F.G.; PEIXOTO, J.R.; BERNACCI, L.C. Potencial de espécies silvestres de maracujazeiro como fonte de resistência a doenças. In: FALEIRO, F.G.; JUNQUEIRA, N.T.V.; BRAGA, M.F. (Ed.). Maracujá: germoplasma e melhoramento genético. Planaltina, DF: Embrapa Cerrados, 2005. p. 81-108.

JUNQUEIRA, N.T.V.; FALEIRO, F.G.; BRAGA, M.F.; PEIXOTO, J.R. Uso de espécies silvestres de Passiflora no pré-melhoramento do maracujazeiro. In: LOPES, M.A.; FÁVERO, A.P.; FERREIRA, M.A.J.F.; FALEIRO, F.G. (Ed.). Curso internacional de pré-melhoramento de plantas. Brasília: Embrapa, 2006. p. 133-137.

JUNQUEIRA, N.T.V.; VERAS, M.C.M.; CHAVES, E.C. Manejo da floração do maracujazeiro. Brasília: Embrapa, 2001. p.1-3. (Recomendação Técnica, 45)

MARTIN, F.W.; NAKASONE, H.Y. The edible species of Passiflora. Economic Botanic, New York, v.24, n.3, p.333-343, 1970.

MELETTI, L.M.M. Maracujá: produção e comercialização no Estado de São Paulo. Boletim Técnico IAC, Campinas, v.158, p.22, 1995.

MENZEL, C. M.; SIMPSON, D. R. Effect of continuous shading on growth, flowering and nutrient uptake of passionfruit. Scientia Horticulturae, Amsterdam, v.35, n.1, p.77-78, 1988.

PIZA JÚNIOR, C. T. A cultura do maracujá. Campinas: CATI, 1991. 71p.

SENTER, S.D., PAYNE, J.A., KNIGHT, R.J., AMIS, A.A. Yield and quality of juice from passion fruit (Passiflora edulis), maypops (Passiflora incarnata) and tetraploid passion fruit hybrids ( $P$. edulis x $P$. incarnata). Journal of the Science Food and Agriculture, London, v.62, n.1, p.67-70, 1993.
SILVA, C.N. Fenologia de espécies silvestres de maracujazeiro e caracterização morfoagronômica e molecular de progênies de meio-irmãos de maracujá maçã (Passiflora maliformis L.). 2017.98 f. Dissertação (Mestrado em Agronomia) - Departamento de Agronomia e Medicina Veterinária, Universidade de Brasília, Brasília, 2017.

SOUZA, L.S.; JUNQUEIRA, N.T.V.; LIMA, C.A.; SILVA, D.G.P.; FALEIRO, F.G.; CAMPOS NETO, F.CORREA; BERNACCI, L.C. Determinação da compatibilidade genética entre espécies de passifloras visando à obtenção de híbridos resistentes a doenças. In: SIMPÓSIO INTERNACIONAL DE SAVANAS TROPICAIS, 2., 2008, Brasília. Anais... Brasília: Embrapa, 2008. Disponível em: <http://simposio.cpac. embrapa.br/simposio\%20em\%20pc210\%20(Pc210)/ fichas/00609_trab1_ficha.pdf>. Acesso em: 02 abr. 2017.

TEIXEIRA, C.G.I. Maracujá: cultura, matéria-prima, processamento e aspectos econômicos. 2. ed. Campinas: Instituto de Tecnologia de Alimentos, 1994. p. 367.

TELES, D.A.A.; JUNQUEIRA, N.T.V.; FALEIRO, F.G.; GOLÇALVEZ, M.G.S.; BRAGA, M.F.; ABRANTES, P.H.R. Características físicas e químicas de oito genótipos de Passiflora maliformis Linn. cultivados no Distrito Federal. In: CONGRESSO BRASILEIRO DE FRUTICULTURA, 22., 2012, Bento Gonçalvez: Anais... Bento Gonçalvez: Sociedade Brasileira de Fruticultura, 2012. Disponível em: $<$ https://www.alice.cnptia.embrapa. br/alice/bitstream/doc/941149/1/CD416 Nilton11.pdf $>$. Acesso em: 02 abr. 2017.

VANDERPLANK, J. Passion flowers and passion fruit. London: Cassel, 1991. 176p.

VÁSQUEZ, R., COIMBRA, G. Frutas silvestres comestibles de Santa Cruz. Santa Cruz: Gobierno Municipal de Santa Cruz de la Sierra, 1996. 267p.

WATSON, D. P.; BOWERS, F. A. Long days produce flowers on passionfruit. Hawaii Farm Science, Honolulu, v.14, n.2, p.3-5, 1965.

WINKS, C.W., MENZEL, C.M., SIMPSON, D.R. Passionfruit in Queensland - Botany and cultivars. Queensland Agriculture Journal, Brisbane, v.114, n.4, p.217-224, 1988. 